\title{
Effects of carbon and nitrogen content on seed germination of calabrian pine (Pinus brutia) populations
}

\author{
Efectos del contenido de carbono y nitrógeno en la germinación de semillas de poblaciones de pino \\ de Calabria (Pinus brutia)
}

\author{
Servet Caliskan ${ }^{a *}$, Ender Makineci ${ }^{\mathrm{b}}$ \\ *Corresponding author: ${ }^{a}$ Istanbul University, Faculty of Forestry, Silviculture Department, 34473 Bahcekoy, \\ Sariyer, Istanbul, Turkey, servetc@istanbul.edu.tr \\ ${ }^{\mathrm{b}}$ Istanbul University, Faculty of Forestry, Soil Science and Ecology Department, 34473 Bahcekoy, Sariyer, Istanbul, Turkey.
}

\begin{abstract}
SUMMARY
Calabrian pine (Pinus brutia) seeds collected from fifteen populations were analyzed for their carbon (C) and nitrogen (N) content. Moreover, germination percentages (GP) and mean germination times (MGT) of the seeds were evaluated based on their carbon and nitrogen concentrations, $\mathrm{C} / \mathrm{N}$ ratio, total carbon mass $(\mathrm{CM})$, and total nitrogen mass $(\mathrm{NM})$. Except for $\mathrm{C} / \mathrm{N}$ ratios, variables showed significant differences among populations. The highest seed carbon concentration was $54 \%$, and the lowest was $50 \%$. Seed nitrogen concentrations varied from $2.6 \%$ to $3.2 \%$. The highest correlations were found between the GP of chilled filled seeds (GPFS) and the combined concentrations of carbon and nitrogen $\left(\mathrm{R}^{2}=0.65\right)$ and the GPFS and concentrations of carbon $\left(\mathrm{R}^{2}=0.63\right)$, both being significant. The relationships between germination parameters and combined concentrations of carbon and nitrogen as well as $\mathrm{CM}$ and NM traits were generally higher than any found in individual evaluations, except for the concentrations of carbon.
\end{abstract}

Key words: calabrian pine, seed, carbon, nitrogen, germination, chilled seed, Turkey.

\section{RESUMEN}

Semillas de pino de Calabria (Pinus brutia) recolectadas de 15 poblaciones fueron analizados en su contenido de carbono (C) y nitrógeno $(\mathrm{N})$. Además fueron evaluados los porcentajes de germinación (GP) y tiempos medios de germinación (MGT) de las semillas según sus concentraciones de carbono y nitrógeno, relación $\mathrm{C} / \mathrm{N}$, masa total de carbono $(\mathrm{CM})$ y masa total de nitrógeno $(\mathrm{NM})$. Excepto en las relaciones $\mathrm{C} / \mathrm{N}$, las variables mostraron diferencias significativas entre las poblaciones. La mayor concentración de carbono de las semillas fue de $54 \%$, y la más baja fue de $50 \%$. Las concentraciones de nitrógeno en las semillas variaron de 2,6 a $3,2 \%$. Las correlaciones más altas se encontraron entre el GP de las semillas estratificadas (GPFS) y las concentraciones combinadas de carbono y nitrógeno $\left(\mathrm{R}^{2}=0,65\right)$, y entre los GPFS y concentraciones de carbono $\left(\mathrm{R}^{2}=0,63\right)$, ambas significativas. Las relaciones entre los parámetros de germinación y las concentraciones combinadas de carbono y nitrógeno, así como los rasgos CM y NM fueron generalmente mayores que cualquiera de las evaluaciones individuales, a excepción de las concentraciones de carbono.

Palabras clave: pino de Calabria, semillas, carbono, nitrógeno, germinación, semillas estratificadas, Turquía.

\section{INTRODUCTION}

Calabrian pine (Pinus brutia Ten.) is a dominant tree species in the eastern part of the Mediterranean Region, whereas aleppo pine (Pinus halepensis Mill.) is more common in the western part. Both of these pine species have been the primary focus of reforestation in the Mediterranean basin. Its fast growth, adaptation to drought and useful wood also increased the interest in calabrian pine at international scale and it became an interesting subject for many investigations (Boydak et al. 2006). Calabrian pine is one of the important native forest tree species of Turkey. It usually grows in pure stands and is also a valuable source of timber production. In addition, it provides soil stabilization and serves as a wildlife habitat (Boydak 2004). Among native forest-tree species, it shows the highest distribution area, accounting for $27 \%$ of Turkey's total forest area (5.9 million hectares) (Anonymous 2012).

Seed reserve materials play a vital role in the life strategies of plants (Soriano et al. 2011), and seed germination is also affected by the use and storage of these reserve materials (Bewley 1997, Borisjuk et al. 2004, Fait et al. 2006). Furthermore, the nitrogen $(\mathrm{N})$ and carbon $(\mathrm{C})$ contents of seeds are considered to be reliable indicators (Toorop et al. 2012) among seed reserve materials. The nitrogen and protein ratios of seeds have a substantial effect on the plant efficacious use of nitrogen as well as seed quality 
and nutrition (Masclaux-Daubresse and Chardon 2011). Moreover, during the first stage of seed germination, an adequate supply of nitrogen is necessary in order to satisfy the amino acid requirements of the seed needed for protein synthesis (Soriano et al. 2011).

Seed development represents the carbon sink of the plant (Wardlaw 1990, Way et al. 2010), and accumulation of carbon in seeds is directly related to the photosynthesis mechanism (Borrel et al. 2001, Gregersen et al. 2008, Masclaux-Daubresse and Chardon 2011). Additionally, in higher quality seeds, increased levels of carbon fixation occur in conjunction with the accumulation of increased levels of other nutrients, including nitrogen (Huxman et al. 1999).

Literature contains a limited number of studies that have focused on the carbon and nitrogen content and carbon/nitrogen ratios of forest tree seeds in Turkey (Gül 1992, Matthaus and Özcan 2011, Caliskan and Makineci 2014) and the relationship between these ratios and seed germination.

Hence, the main aims of this study were: (1) to compare carbon and nitrogen content, carbon/nitrogen ratio, total carbon mass, and total nitrogen mass in the seeds of fifteen different calabrian pine populations, and (2) to evaluate the relationships between carbon and nitrogen content of seeds and germination parameters.

In relation to the aims, the specific hypotheses of the study are: 1) $\mathrm{H}_{0}$ : The seed lots of different calabrian pine populations have no variation in carbon and nitrogen concentrations, carbon/nitrogen ratio, carbon mass, and nitrogen mass. 2) $\mathrm{H}_{0}$ : The carbon and nitrogen contents of seeds have no effect on germination parameters.

\section{METHODS}

Seed material. Cones were collected from fifteen calabrian pine seed stands by the Turkish Ministry of Forest and Water Affairs, Forest Tree Seeds and Tree Breeding Research Directorate. In each seed stand, cones were collected from more than 100 mature trees. After removed from the cones, all the seeds were then combined into single seed lots representing each population. The geographic locations of the seed stands are given in table 1 and figure 1.

Screens were used to clean and separate every seed lot from the twigs, needles and other particles, and damaged and insect-infested seeds were eliminated by hand selection (Schmidt and Thomsen 2003, Karrfalt 2008). The remaining seeds were stored at $3{ }^{\circ} \mathrm{C}\left( \pm 1^{\circ} \mathrm{C}\right)$. In each clean seed lot, randomly selected seeds were subjected to germination tests as well as carbon and nitrogen analyses. Furthermore, 1,000 - seed weights (g) were determined based on eight replications of 100 seeds (ISTA 1999). Since calabrian pine seeds have chilling requirements (Boydak et al. 2006, Şefik 1964, 1965, Aslan and Uğurlu 1986, Skordilis and Thanos 1995, Thanos 2000) the seeds were chilled at $+3{ }^{\circ} \mathrm{C}\left( \pm 1{ }^{\circ} \mathrm{C}\right)$ for 45 days.
Germination tests. Germination tests were performed in petri dishes measuring $9 \mathrm{~cm}$ in diameter on two layers of filter paper saturated with deionized water and were carried out using four replicates of 50 seeds each at a constant temperature of $20^{\circ} \mathrm{C}\left( \pm 0.5^{\circ} \mathrm{C}\right)$. Seeds were considered to be germinated when geotropism occurred in the radicles and a growth of more than $5 \mathrm{~mm}$ in length from the seed coat was seen. Experiments were checked every day over a 28-day period, and the germinated seeds were then removed from the petri dishes. Next, the ungerminated seeds were subjected to a cut test to determine the proportion of sound and empty seeds in every replication of each treatment. Germination data were expressed in terms of germination percentages (GP) [the germination percentage of the total seeds in the control group (GPC) (unchilled), the germination percentage of filled seeds in the control group (GPFC) (unchilled), the germination percentage of the total number of pretreated seeds (GPS) (chilled), and the germination percentage of pretreated filled seeds (GPFS) (chilled)] and mean germination times (MGT) [the mean germination time of the seeds in the control group (MGTC) (unchilled) and the mean germination time of the chilled seeds (MGTS)]. MGTs were calculated using the following formula [1] (Bewley and Black 1994) in which $t$ represents the time in days starting from the day the tests began, and $n$ is the number of seeds which completed germination on day $t$. In this equation, lower MGT values indicate quicker germination:

$$
M G T=\sum(t \times n) / \sum n
$$

Carbon and nitrogen analyses. The seed samples (30 seeds for each replication) were ground, and the Dumas dry combustion method was utilized to determinate carbon and nitrogen concentrations using a LECO Truspec 2000 $\mathrm{CN}$ analyzer (LECO Corporation, St. Joseph, MI, USA) (Leco 2000) with 10 replicates for each population. Carbon mass (CM) and nitrogen mass (NM) were then calculated from the carbon-nitrogen concentration and seed mass.

Statistical analyses. Prior to the statistical evaluation, the arcsine square root transformation was used for GPs, and the generalized linear model procedure was employed for the analysis of variance (ANOVA). The following model was used to calculate the ANOVA for the seed traits:

$$
y_{i j}: \mu+P_{i}+e_{i j}
$$

In this model, $y_{i j}$ represents the trait of $j$ in the replication of the $i$ population $(j=1,2,3$, and 4 for GPs and MGTs and $j=1,2,3, \ldots, 10$ for carbon concentrations, nitrogen concentrations, $\mathrm{C} / \mathrm{N}$ ratio, carbon mass, and nitrogen mass); $\mu$ signifies the overall mean; $P_{i}$ represents the effect due to the $i$ population $(i: 1,2,3, \ldots 15)$; and $e_{i j}$ stands for the error. 
Table 1. Seed collection sites of calabrian pine.

Sitios de colecta de semillas de pino de Calabria.

\begin{tabular}{|c|c|c|c|c|c|}
\hline & Populations & Altitude (m) & Latitude $\left({ }^{\circ} \mathrm{N}\right)$ & Longitude $\left({ }^{\circ} \mathrm{E}\right)$ & Exposure \\
\hline 1 & Pos-Soğukoluk & 735 & 373524 & 352128 & $\mathrm{~S}$ \\
\hline 2 & Pos-Karsant1 & 735 & 373430 & 352430 & W-NW \\
\hline 3 & MKPaşa-Çaltılıbük & 250 & 395845 & 284054 & NE \\
\hline 4 & Marmaris-Çetibeli & 60 & 370017 & 281942 & NW \\
\hline 5 & Muğla-Karabörtlen & 680 & 370533 & 283222 & Plain \\
\hline 6 & Y1lanl1-Boyal1 & 750 & 371718 & 283350 & N-SE \\
\hline 7 & Muğla-Gökova & 270 & 370039 & 282430 & NW \\
\hline 8 & Durağan-Adadağ 1 & 400 & 412713 & 350603 & N-W \\
\hline 9 & Amasya-Destek & 430 & 405343 & 362119 & W \\
\hline 10 & Ayvackk-Baharlar & 450 & 393624 & 263432 & N-S \\
\hline 11 & Yenice-Yenice & 300 & 395604 & 272057 & NW \\
\hline 12 & Geyve-Taraklı & 530 & 402312 & 302513 & $\mathrm{~N}$ \\
\hline 13 & Andırın-Kesim & 400 & 372418 & 362342 & E \\
\hline 14 & Serik-Pınargözü & 500 & 371714 & 305757 & W-SW \\
\hline 15 & Antalya-Düzlerçamı & 275 & 365945 & 303310 & Plain \\
\hline
\end{tabular}

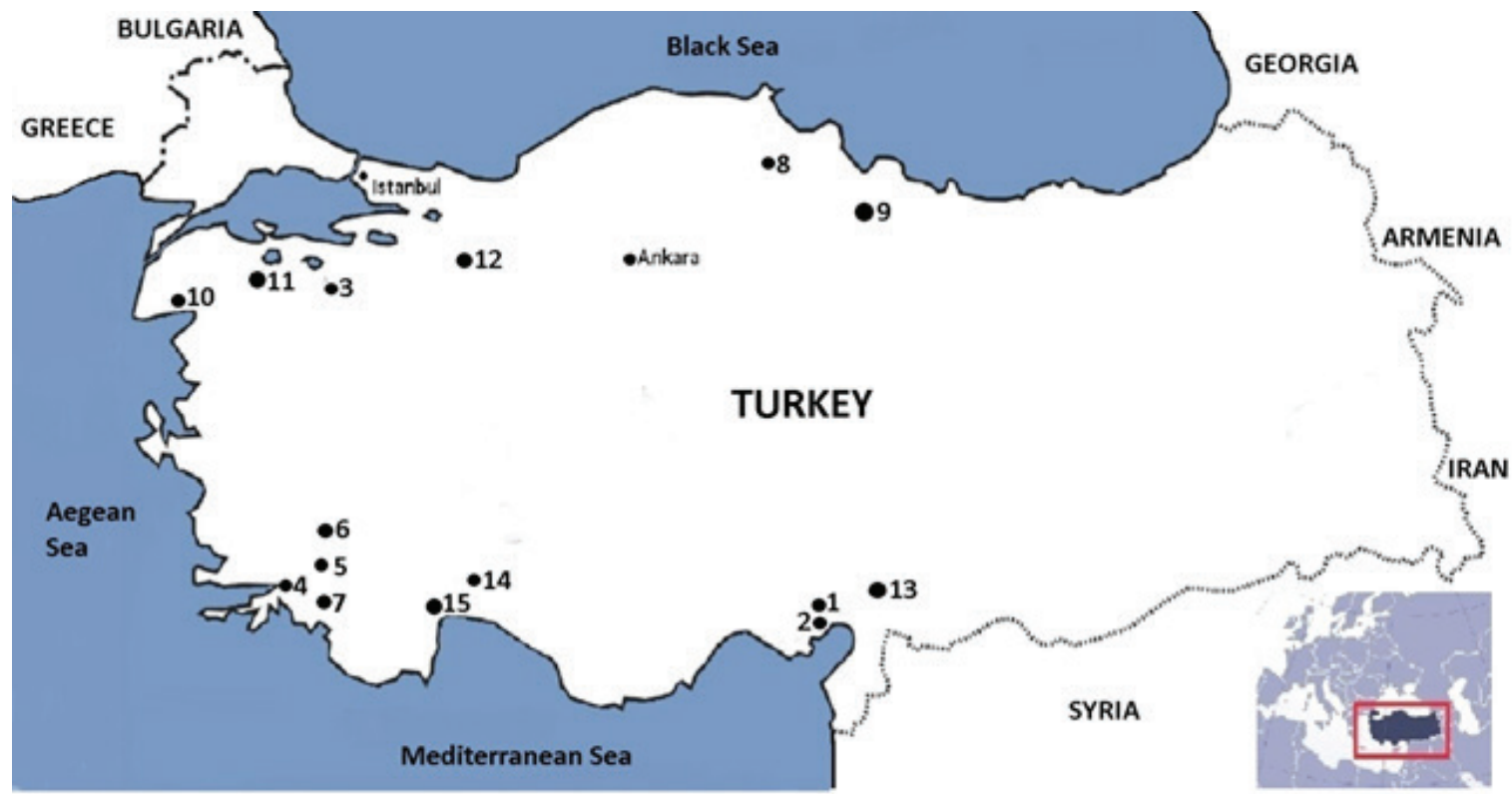

Figure 1. The location of calabrian pine populations.

Localización de las poblaciones de pino de Calabria.

In addition, Duncan's post hoc test was used to determine the significant differences among means $(P<0.05)$. Furthermore, the magnitude of the variation (as a percentage of the total variation) due to population and error was evaluated for each trait using the restricted maximum likelihood method, and the coefficient of variation was then determined based on the overall mean and total variance for each trait. Correlations were also calculated to examine the relationship among carbon concentrations, nitrogen concentrations, carbon/nitrogen ratio, carbon mass, and nitrogen mass along with germination parameters. In addition, suitable regression models were used to evaluate the significant relationships between germination parameters and the chemical traits of seeds. 


\section{RESULTS}

The lowest seed carbon concentration (50\%) was found in the Antalya-Düzlerçamı population, whereas the highest concentration (54\%) was in Ayvackk-Baharlar (table 2). ANOVA results revealed significant $(P=0.0001)$ differences among the calabrian pine populations with regard to the carbon concentration of seeds. Furthermore, according to the results of the Duncan test, the AyvacikBaharlar, Andırın-Kesim, and Antalya-Düzlerçamı populations were ranked individually while the others were ranked in different groups (table 2). The seed nitrogen concentrations of the populations varied from $2.6 \%$ in Yılanlı-Boyalı and Andırın Kesim to $3.2 \%$ in MuğlaGökova and Antalya-Düzlerçamı, and these concentrations demonstrated statistically significant differences $(P=0.0126)$ among populations (table 2$)$. However, $\mathrm{C} / \mathrm{N}$ ratios showed no significant $(P=0.0883)$ differences, with ratios of between 15.7 in Antalya-Düzlerçamı and 21.8 in Andırın-Kesim (table 2). Maximum carbon mass and nitrogen mass were $34.5 \mathrm{~g}$ in Durağan-Adadağ $\breve{1}$ and $2.0 \mathrm{~g}$ in Pos-Karsantı and Ayvacık-Baharlar, respectively (table 2); while minimum carbon mass and nitrogen mass were $26.4 \mathrm{~g}$ in Yenice-Yenice and $1.4 \mathrm{~g}$ in Yllanl1-Boyalı and Andırın-Kesim, respectively (table 2).

Significant differences $(P=0.0001)$ related to GPC, GPFC, GPS, GPFS, MGTC and MGTS were also found among the different calabrian pine populations. For example, GPC ranged from $19.5 \%$ in Amasya-Destek to $85 \%$ in Antalya-Düzlerçamı while the MGTC ranged from 12.8 in Yenice-Yenice to 18.2 in Amasya-Destek. Furthermore, the lowest MGTS rate of 10.0 was found in the Mugla-Gökova population, while the highest rate of 14.4 was located in Andirın-Kesim (table 2). Additionally, the seed weights of the calabrian pine populations ranged from $38.4 \mathrm{~g}$ in Andırın-Kesim to $55.5 \mathrm{~g}$ in Serik-Pınargözü, and the mean seed weight of all of the populations was $47.8 \mathrm{~g}$ (table 2).

The highest correlation was found between GPFS and the combined concentrations of carbon and nitrogen $\left(\mathrm{R}^{2}=\right.$ $0.65)$. This was followed by GPFS and concentration of carbon $\left(R^{2}=0.63\right)$; both of these relationships were significant. The relationships between the germination parameters in the combined concentration of carbon and nitrogen and the combined traits of carbon mass and nitrogen mass were generally higher than those found in the individual evaluations, except for the concentration of carbon. The regression models with $P<0.05$ are given below (table 3 ).

$(\mathrm{GPC}): \mathrm{y}=534.103-\mathrm{X}_{1} * 9.297 ;\left(\mathrm{X}_{1}=\% \mathrm{C}\right) ; \mathrm{R}^{2}=0.34 ; \mathrm{S}_{\mathrm{e}}$ $=16.63 ; P=0.024$

(GPC): $y=448.688-X_{1}^{*} 10.141+X_{2} * 43.744 ;\left(X_{1}=\%\right.$ $\left.\mathrm{C}, \mathrm{X}_{2}=\% \mathrm{~N}\right) ; \mathrm{R}^{2}=0.50 ; \mathrm{S}_{\mathrm{e}}=15.08 ; P=0.017$

(GPS): $\mathrm{y}=464.007-\mathrm{X}_{1} * 7.9998 ;\left(\mathrm{X}_{1}=\% \mathrm{C}\right) ; \mathrm{R}^{2}=0.47$; $\mathrm{S}_{\mathrm{e}}=10.80 ; P=0.005$
(GPS): $\mathrm{y}=424.868-\mathrm{X}_{1} * 8.386+\mathrm{X}_{2} * 20.045 ;\left(\mathrm{X}_{1}=\% \mathrm{C}\right.$, $\left.\mathrm{X}_{2}=\% \mathrm{~N}\right) ; \mathrm{R}^{2}=0.53 ; \mathrm{S}_{\mathrm{e}}=10.55 ; P=0.010$

$(\mathrm{MGTS}): \mathrm{y}=24.429-\mathrm{X}_{1} * 4.136 ;\left(\mathrm{X}_{1}=\% \mathrm{~N}\right) ; \mathrm{R}^{2}=0.30 ; \mathrm{S}_{\mathrm{e}}$ $=1.19 ; P=0.034$

$(\mathrm{GPFC}): \mathrm{y}=774.402-\mathrm{X}_{1} * 13.722 ;\left(\mathrm{X}_{1}=\% \mathrm{C}\right) ; \mathrm{R}^{2}=0.50$; $\mathrm{S}_{\mathrm{e}}=17.29 ; P=0.003$

(GPFC): $\mathrm{y}=693.536-\mathrm{X}_{1} * 14.520+\mathrm{X}_{2} * 41.415 ;\left(\mathrm{X}_{1}=\%\right.$ $\left.\mathrm{C}, \mathrm{X}_{2}=\% \mathrm{~N}\right) ; \mathrm{R}^{2}=0.60 ; \mathrm{S}_{\mathrm{e}}=16.10 ; P=0.004$

(GPFC): $\mathrm{y}=185.073-\mathrm{X}_{1} * 10.786+\mathrm{X}_{2} * 116.405 ;\left(\mathrm{X}_{1}=\right.$ carbon mass, $\mathrm{X}_{2}=$ nitrogen mass); $\mathrm{R}^{2}=0.44 ; \mathrm{S}_{\mathrm{e}}=19.12$; $P=0.031$

(GPFS): $\mathrm{y}=659.148-\mathrm{X}_{1} * 11.564 ;\left(\mathrm{X}_{1}=\% \mathrm{C}\right) ; \mathrm{R}^{2}=0.63$; $\mathrm{S}_{\mathrm{e}}=11.29 ; P=0.0004$

(GPFS): $\mathrm{y}=630.839-\mathrm{X}_{1} * 11.844+\mathrm{X}_{2} * 14.498 ;\left(\mathrm{X}_{1}=\right.$ $\left.\% \mathrm{C}, \mathrm{X}_{2}=\% \mathrm{~N}\right) ; \mathrm{R}^{2}=0.65 ; \mathrm{S}_{\mathrm{e}}=11.41 ; P=0.002$

According to results, the amount of variation due to the populations was higher for germination parameters than for seed chemical traits (table 4), and the coefficient of variation of GPs and MGTs ranged from $22.1-28.3$ and 5.4 - 6.0, respectively. The coefficient of variation of carbon concentration, nitrogen concentration, carbon/nitrogen ratio, carbon mass, and nitrogen mass varied between 4.3 and 22.7 (table 4).

\section{DISCUSSION}

The results of this study demonstrated that all seed parameters, except for carbon/nitrogen ratio, differed significantly among the investigated calabrian pine populations. With regard to the relationships between carbon and nitrogen contents of seeds and germinations traits, the highest correlation existed between GPFS and the combined concentration of carbon and nitrogen followed by the correlation between GPFS and concentration of carbon. As our results showed, the seed carbon concentration had a stronger effect on GP and MGT parameters than that posed by the seed nitrogen concentration and carbon/nitrogen ratios. These results demonstrate that factors other than those related to the populations themselves may play a role on the observed variations in these population differences. For example, the nitrogen supply of the trees might have a direct effect on the nitrogen concentration of their seeds (Munier-Jolain et al. 2008, Masclaux-Daubresse et al. 2010, Masclaux-Daubresse and Chardon 2011). Moreover, our results indicated that carbon is a more stable parameter in seeds, whereas nitrogen is characteristically more variable. For instance, in contrast to carbon, nitrogen in the seeds of growing plants is largely obtained through the recycling of nitrogen sources that are assimilated prior 


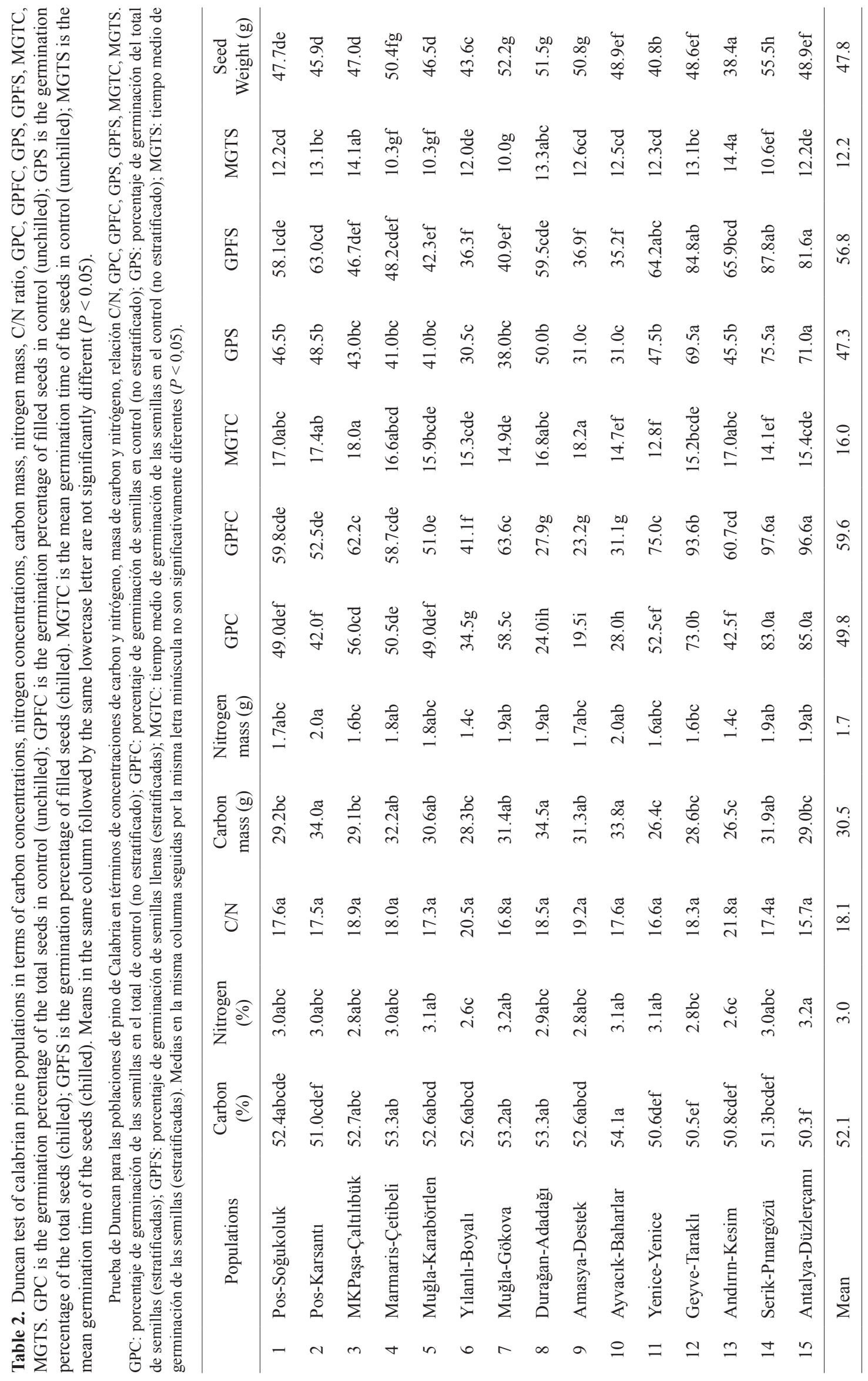


Table 3. Relationships between the chemical traits and germination parameters in calabrian pine seeds.

Relaciones entre características químicas y parámetros de germinación en semillas de pino de Calabria.

\begin{tabular}{|c|c|c|c|c|c|c|c|c|}
\hline Variable & Parameter & $\begin{array}{c}\text { Carbon } \\
\%\end{array}$ & $\begin{array}{c}\text { Nitrogen } \\
\%\end{array}$ & $\begin{array}{l}\text { Carbon/ } \\
\text { Nitrogen }\end{array}$ & $\begin{array}{c}\text { Carbon } \\
\text { mass }\end{array}$ & $\begin{array}{l}\text { Nitrogen } \\
\text { mass }\end{array}$ & $\% \mathrm{C}-\% \mathrm{~N}$ & $\begin{array}{l}\text { Carbon mass - } \\
\text { nitrogen mass }\end{array}$ \\
\hline GPC & $\begin{array}{c}\mathrm{R}^{2} \\
\mathrm{~S}_{\mathrm{e}} \\
P \text {-value }\end{array}$ & $\begin{array}{c}0.34 \\
16.63 \\
0.0236\end{array}$ & $\begin{array}{c}0.10 \\
19.32 \\
0.2426\end{array}$ & $\begin{array}{c}0.24 \\
17.78 \\
0.0638\end{array}$ & $\begin{array}{c}0.10 \\
19.35 \\
0.2514\end{array}$ & $\begin{array}{c}0.00 \\
20.39 \\
0.9037\end{array}$ & $\begin{array}{c}0.50 \\
15.08 \\
0.0165\end{array}$ & $\begin{array}{c}0.38 \\
16.78 \\
0.0596\end{array}$ \\
\hline MGTC & $\begin{array}{c}\mathrm{R}^{2} \\
\mathrm{~S}_{\mathrm{e}} \\
P \text {-value }\end{array}$ & $\begin{array}{c}0.05 \\
1.53 \\
0.4233\end{array}$ & $\begin{array}{c}0.16 \\
1.43 \\
0.1344\end{array}$ & $\begin{array}{c}0.20 \\
1.40 \\
0.0910\end{array}$ & $\begin{array}{c}0.05 \\
1.53 \\
0.4389\end{array}$ & $\begin{array}{c}0.01 \\
1.56 \\
0.7724\end{array}$ & $\begin{array}{c}0.24 \\
1.42 \\
0.1904\end{array}$ & $\begin{array}{c}0.26 \\
1.40 \\
0.1631\end{array}$ \\
\hline GPS & $\begin{array}{c}\mathrm{R}^{2} \\
\mathrm{~S}_{\mathrm{e}} \\
P \text {-value }\end{array}$ & $\begin{array}{c}0.47 \\
10.80 \\
0.0048\end{array}$ & $\begin{array}{c}0.03 \\
14.64 \\
0.5668\end{array}$ & $\begin{array}{c}0.14 \\
13.75 \\
0.1692\end{array}$ & $\begin{array}{c}0.01 \\
14.73 \\
0.6721\end{array}$ & $\begin{array}{c}0.02 \\
14.71 \\
0.6568\end{array}$ & $\begin{array}{c}0.53 \\
10.55 \\
0.0103\end{array}$ & $\begin{array}{c}0.17 \\
14.05 \\
0.3218\end{array}$ \\
\hline MGTS & $\begin{array}{c}\mathrm{R}^{2} \\
\mathrm{~S}_{\mathrm{e}} \\
P \text {-value }\end{array}$ & $\begin{array}{c}0.08 \\
1.36 \\
0.2970\end{array}$ & $\begin{array}{c}0.30 \\
1.19 \\
0.0343\end{array}$ & $\begin{array}{c}0.26 \\
1.22 \\
0.0518\end{array}$ & $\begin{array}{c}0.06 \\
1.38 \\
0.3716\end{array}$ & $\begin{array}{c}0.16 \\
1.30 \\
0.1367\end{array}$ & $\begin{array}{c}0.35 \\
1.19 \\
0.0763\end{array}$ & $\begin{array}{c}0.18 \\
1.33 \\
0.2940\end{array}$ \\
\hline GPFC & $\begin{array}{c}\mathrm{R}^{2} \\
\mathrm{~S}_{\mathrm{e}} \\
P \text {-value }\end{array}$ & $\begin{array}{c}0.50 \\
17.29 \\
0.0030\end{array}$ & $\begin{array}{c}0.05 \\
23.96 \\
0.4315\end{array}$ & $\begin{array}{c}0.16 \\
22.45 \\
0.1337\end{array}$ & $\begin{array}{c}0.19 \\
22.10 \\
0.1040\end{array}$ & $\begin{array}{c}0.01 \\
24.48 \\
0.7796\end{array}$ & $\begin{array}{c}0.60 \\
16.10 \\
0.0039\end{array}$ & $\begin{array}{c}0.44 \\
19.12 \\
0.0306\end{array}$ \\
\hline GPFS & $\begin{array}{c}\mathrm{R}^{2} \\
\mathrm{~S}_{\mathrm{e}} \\
P \text {-value }\end{array}$ & $\begin{array}{c}0.63 \\
11.29 \\
0.0004\end{array}$ & $\begin{array}{c}0.00 \\
18.51 \\
0.8831\end{array}$ & $\begin{array}{c}0.06 \\
17.98 \\
0.3847\end{array}$ & $\begin{array}{c}0.05 \\
18.06 \\
0.4199\end{array}$ & $\begin{array}{c}0.00 \\
18.53 \\
0.9513\end{array}$ & $\begin{array}{c}0.65 \\
11.41 \\
0.0018\end{array}$ & $\begin{array}{c}0.18 \\
17.45 \\
0.3014\end{array}$ \\
\hline
\end{tabular}

Table 4. Estimation of variance components and coefficient of variation (CV). Estimación de los componentes de la varianza y coeficiente de variación (CV).

\begin{tabular}{|c|c|c|c|c|}
\hline \multirow{2}{*}{ Characters } & \multirow{2}{*}{ Overall mean } & \multicolumn{2}{|c|}{ Variance components $(\%)$} & \multirow{2}{*}{$\mathrm{CV}(\%)$} \\
\hline & & Population & Error & \\
\hline Nitrogen $(\%)$ & 3.0 & 10 & 90 & 13.9 \\
\hline Carbon (\%) & 52.1 & 22 & 78 & 4.3 \\
\hline Carbon/Nitrogen & 18.1 & 6 & 94 & 21.9 \\
\hline Carbon mass & 30.5 & 24 & 76 & 14.9 \\
\hline Nitrogen mass & 1.7 & 12 & 88 & 22.7 \\
\hline GPC & 49.8 & 95 & 5 & 27.6 \\
\hline GPFC & 59.6 & 95 & 5 & 28.3 \\
\hline MGTC & 16.0 & 61 & 39 & 5.4 \\
\hline GPS & 47.3 & 69 & 31 & 22.1 \\
\hline GPFS & 56.8 & 68 & 32 & 23.7 \\
\hline MGTS & 12.2 & 82 & 18 & 6.0 \\
\hline
\end{tabular}


to seed formation (Cliquet et al. 1990, Patrick and Offler 2001, Masclaux-Daubresse and Chardon 2011). Our findings, which identified the relationship between seed germination parameters and seed carbon and nitrogen concentration, were similar to those of Frenne et al. (2011), who found that the seed carbon concentration had a stronger effect on GP and MGT than the effect observed in seed nitrogen concentrations and $\mathrm{C} / \mathrm{N}$ ratios. They also determined that there was a relationship of $\mathrm{R}^{2}=0.69$ between the seed germination rate and seed carbon concentrations and a relationship of $\mathrm{R}^{2}=0.11$ between the seed germination rate and seed nitrogen concentrations.

The effects of germination on the chemical composition and biochemical constituents of seeds vary greatly with the plant species, seed varieties or cultivars and germination conditions (Gallardo et al. 2002). Proteins are necessary for seed germination, and they accumulate after ripening under seed-drying conditions, resulting in the release of dormancy (Gallardo et al. 2002, Chibani et al. 2006). Among the most important parameters that control the process of seed dormancy are changes associated with protein and hormones (Finch-Savage and Leubner-Metzger 2006, Finkelstein et al. 2008, Graeber et al. 2012, Miransari and Smith 2014). In addition, a group of proteins was discovered that inhibit protein degradation and regulators during seed germination (Corre-Menguy et al. 2002, Martinez et al. 2005).

Several studies have also pointed out the role that nitrogen compounds play in stimulating seed germination. For example, they can trigger the germination of Mediterranean species with limited seed reserves such as the aleppo pine (Pinus halepensis) (Thanos and Rundel 1995, Broncano et al. 1998). In another study, Bedi et al. (2009) found significant correlations between GP and nitrogen (protein) content of seeds. Chandrasiri et al. (1987) also identified an increase in nitrogen that was associated with etiolated germination, and Lee and Karunanithy (1990) pointed out that the protein content was $21 \%$ higher in dehulled, germinated soya beans than in ungerminated seeds (as described by Bau et al. 1997). Another study by Ellis and Marshall (1998) also determined that nitrogen fertilization influences seed quality, and Gardarin et al. (2011) demonstrated that seed protein content had no significant influence on the germination speed parameters that were measured in 25 weed species. Ene and Bean (1975) also found a correlation between the nitrogen content of ryegrass seeds and the germination rate, and this correlation $\left(\mathrm{R}^{2}=0.61\right)$ was statistically significant $(P=0.01)$. On the other hand, Broncano et al. (1998) found that nitrogen supply had no significant effect on seed germination in the Aleppo pine. Frenne et al. (2011) reported a weak relationship between the seed germination rate and seed nitrogen content. In addition, Hara and Toriyama (1998) emphasized the existence of a negative relationship $\left(\mathrm{R}^{2}=0.78\right)$ between the seed nitrogen concentration and germination time. They also reported that proteins (nitrogen) can absorb more wa- ter than lipids or polysaccharides, meaning that more water absorption occurs at a faster pace when there is a higher nitrogen concentration in seeds. In turn, they reasoned that this can lead to increased seed germination.

Limited literature (Gül 1992, Matthaus and Özcan 2011, Caliskan and Makineci 2014) has focused on the carbon, nitrogen contents of forest tree seeds and the relationship between these ratios and germination. We identified low or moderate relationships in the regression models in which individual carbon and nitrogen concentration were used, and these were statistically significant. As seen in these significant models, nitrogen showed a weak relationship only with MGTS $\left(\mathrm{R}^{2}=0.30\right)$, but seed carbon concentrations and carbon mass and nitrogen mass generally demonstrated a moderate correlation with GPC, GPS, GPFC and GPFS. Furthermore, we obtained stronger relationships for germination parameters, except for MGTS, with combined carbon and nitrogen concentrations and carbon mass and nitrogen mass. Similarly, Caliskan and Makineci (2014) concluded that a positive linear relationship existed between carbon and nitrogen concentrations and GP, and that there was a negative relationship between carbon and nitrogen concentrations and MGT in Mediterranean cypress (Cupressus sempervirens L.) seeds. They also obtained more significant results by combining seed carbon and nitrogen concentrations on the regression models to estimate GP and MGT.

\section{CONCLUSIONS}

The seed lots of different calabrian pine populations show variation in carbon concentrations, nitrogen concentrations, carbon/nitrogen ratio, carbon mass, and nitrogen mass; these traits would have effect on the germination parameters. Variables show significant differences among populations except $\mathrm{C} / \mathrm{N}$ ratios. The Antalya-Düzlerçamı population have the highest seed nitrogen concentration and the highest germination percentages. The highest significant correlation there is between GPFS in chilled seeds and the combined concentration of carbon and nitrogen. The relationships of germination parameters in the combined concentration of carbon and nitrogen and combination of carbon mass and nitrogen mass traits are also generally higher. If it is to continue to have a significant role in afforestation in this region, the quality of the seeds and seedlings must be maintained. While we believe that our findings shed some light on this topic, future research is needed to ensure the sustainability of this native species.

\section{ACKNOWLEDGEMENTS}

This work was supported by the Scientific Research Projects Coordination Unit of Istanbul University (project no. 41567). We are grateful to the Turkish Ministry of Forest and Water Affairs, Forest Tree Seeds and Tree Breeding Research Directorate for the seed collection used in this study. 


\section{REFERENCES}

Anonymous 2012. State of Turkish Forest. The Turkish Ministry of Forest and Water Affairs, Ankara. 25 p. (In Turkish).

Aslan S, S Uğurlu. 1986. Seed and seedling characteristics of different Pinus brutia Ten., Pinus halepensis Mill. and Pinus elderica Medweed provenances. Ormancılık Araştırma Enstitüsü Yayınları, Teknik Bülten Serisi. Ankara No. 165. 54 p. (In Turkish, with English summary).

Bau HM, C Villaume, JP Nicolas, L Mejean. 1997. Effect of germination on chemical composition, biochemical constituents and antinutritional factors of soya bean (Glycine max) seeds. Journal of the Science of Food and Agriculture 73(1): 1-9.

Bedi S, S Mehta, S Sharma, KV Kumar. 2009. Nitrogen nutrition and efficiency of seed reserve mobilization during germination in winter maize cv. 'Buland'. Journal of New Seeds 10(1): 57-61.

Bewley JD. 1997. Seed germination and dormancy. Plant and Cell 9: 1055-1066.

Bewley JD, M Black. 1994. Seeds: Physiology of Development and Germination. New York, USA. Plenum Press. 445 p.

Borisjuk L, H Rolletschek, R Radchuk, W Weschke, U Wobus, H Weber. 2004. Seed development and differentiation: a role for metabolic regulation. Plant Biology 6: 375-386.

Borrel A, G Hammer, E Van Osterom. 2001. Stay-green: a consequence of the balance between supply and demand for nitrogen during grain filling. Annals of Applied Biology 138: 91-95.

Boydak M. 2004. Silvicultural characteristics and natural regeneration of Pinus brutia Ten.-a review. Plant Ecology 171: 153-163.

Boydak M., H Dirik, M Calikoglu. 2006. Biology and silviculture of Turkish red pine (Pinus brutia Ten.). Ankara, Turkey. OGEM-VAK.

Broncano MJ, M Riba, J Retana. 1998. Seed germination and seedling performance of two Mediterranean tree species, holm oak (shape Quercus ilex L.) and Aleppo pine (shape Pinus halepensis Mill.): a multifactor experimental approach. Plant Ecology 138(1): 17-26.

Caliskan S, E Makineci. 2014. Variations in carbon and nitrogen ratios and their effects on seed germination in Cupressus sempervirens populations. Scandinavian Journal of Forest Research 29(2): 162-169.

Chandrasiri V, HM Bau, C Villaume, F Giannangeli, D Lorient, L Mejean. 1987. Effet de la germination de la graine de soja sur la composition et la valeur nutritionnelle de sa farine. Sciences des Aliments 7: 139-150.

Chibani K, S Ali-Rachedi, C Job, D Job, M Jullien, P Grappin. 2006. Proteomic analysis of seed dormancy in Arabidopsis. Plant Physiology 142(4): 1493-1510.

Cliquet JB, E Deléens, A Mariotti. 1990. C and N mobilization from stalk to leaves during kernel filling by $13 \mathrm{C}$ and $15 \mathrm{~N}$ tracing in Zea mays L. Plant Physiology 94: 1547-1553.

Corre-Menguy F, FJ Cejudo, C Mazubert, J Vidal, C LelandaisBriere, G Torres, A Rode, C Hartmann. 2002. Characterization of the expression of a wheatcystatin gene during caryopsis development. Plant Moleculer Biology 50: 687-698.

Ellis RP, B Marshall. 1998. Growth, yield and grain quality of barley (Hordeum vulgare L.) in response to nitrogen uptake: II. Plant development and rate of germination. Jour- nal of Experimental Botany 49(323): 1021-1029.

Ene BN, EW Bean. 1975. Variations in seed quality between certified seed lots of perennial ryegrass, and their relationship to nitrogen supply and moisture status during seed development. Grass Forage Science 30(3): 195-199.

Fait A, R Angelovici, H Less, I Ohad, E Urbanczyk-Wochniak, AR Fernie, G Galili. 2006. Arabidopsis seed development and germination is associated with temporally distinct metabolic switches. Plant Physiology 142: 839-854.

Finch-Savage W, G Leubner-Metzger. 2006. Seed dormancy and the control of germination. New Phytologist 171: 501-523.

Finkelstein R, W Reeves, T Ariizumi, C Steber. 2008. Molecular aspects of seed dormancy. Annual Review of Plant Biology 59: $387-415$

Frenne PD, A Kolb, BJ Graae, G Decocq, S Baltora, AD Schrijver, J Brunet, O Chabrerie, SAO Cousins, R Dhond, M Diekmann, R Gruwez, T Heinken, M Hermy, J Liira, R Saguez, A Shevtsova, CC Baskin, K Verheyen. 2011. A latitudinal gradient in seed nutrients of the forest herb Anemone nemorosa. Plant Biology 13: 493-501.

Gallardo K, C Job, PC Groot, M Puype, H Demol, J Vandekerckhove, D Job. 2002. Proteomics of Arabidopsis seed germination. A comparative study of wild-type and gibberellins deficient seeds. Plant Physiology 129: 823-837.

Gardarin A, C Dürr, N Colbach. 2011. Prediction of germination rates of weed species: Relationships between germination speed parameters and species traits. Ecological Modelling 222(3): 626-636.

Graeber K, K Nakabayashi, E Miatton, G Leubner-Metzger, W Soppe. 2012. Molecular mechanisms of seed dormancy. Plant Cell and Environment 35: 1769-1786.

Gregersen PL, P Holm, K Krupinska. 2008. Leaf senescence and nutrient remobilisation in barley and wheat. Plant Biology 10: 37-49.

Gül GS. 1992. Palamut Meşesi (Quercus ithaburensis Decne. Subsp. Macrolepis kotschy Hedge et Yalt.) Pelitlerinden Hayvan Beslemede Yararlanma. Ormancılık Araştırma Enstitüsü Dergisi Cilt: 38, Dergi No: 75 (In Turkish).

Hara Y, K Toriyama. 1998. Seed nitrogen accelerates the rates of germination, emergence, and establishment of rice plants. Soil Science and Plant Nutrition 44: 359-366.

Huxman TE, EP Hamerlynck SD Smith. 1999. Reproductive allocation and seed production in Bromus madritensis ssp. rubens at elevated atmospheric $\mathrm{CO}_{2}$. Functional Ecology 13: 769-777.

ISTA (International Seed Testing Association, CH). 1999. International Rules for Seed Testing. Seed Science and Technology 27 (Supplementary). Zurich, Switzerland. ISTA. 333 p.

Karrfalt RP. 2008. Seed Harvesting and Conditioning. In Bonner FT, RP Karrfalt eds. The Woody Plant Seed Manual. United States Department of Agriculture, Forest Service Agriculture Handbook 727. p. 57-84. Available at http://www.nsl. fs.fed.us/nsl_wpsm.html

Leco 2000. TruSpec CN Analyzer. St. Joseph, Missouri, USA. Leco Cooperation.

Lee CK, R Karunanithy. 1990. Effects of germination on the chemical composition of Glycine and Phaseolus beans. Journal of Science Food Agriculture 51(4): 437-445.

Martinez M, Z Abraham, P Carbonero, I Diaz. 2005. Comparative phylogeneticanalysis of cystatin gene families from arabidopsis, rice and barley. Moleculer Genetics Genomics 
273: 423-432

Masclaux-Daubresse C, F Chardon. 2011. Exploring nitrogen remobilization for seed filling using natural variation in Arabidopsis thaliana. Journal of Experimental Botany 6: 2131-2142.

Masclaux-Daubresse C, F Daniel-Vedele, J Dechorgnat, F Chardon, L Gaufichon, A Suzuki 2010. Nitrogen uptake, assimilation and remobilisation in plants: challenges for sustainable and productive agriculture. Annals of Botany 105: 1141-1157.

Matthaus B, MM Özcan. 2011. Lipid evaluation of cultivated and wild carob (Ceratonia siliqua L.) seed oil growing in Turkey. Scientia Horticulturae 130: 181-184.

Miransari M, DL Smith. 2014. Plant hormones and seed germination. Environmental and Experimental Botany 99: 110-121.

Munier-Jolain N, A Larmure, C Salon 2008. Determinism of carbon and nitrogen reserve accumulation in legume seeds. Comptes Rendus Biologies 331(10): 780-787.

Patrick JW, CE Offler. 2001. Compartmentation of transport and transfer events in developing seeds. Journal of Experimental Botany 52: 551-564.

Schmidt HL, AK Thomsen. 2003. Tree seed processing. In Smith RD, JB Dickie, SH Linington, HW Pritchard, RJ Probert eds. Seed conservation turning scienceinto practice. Kew Publishing. Available from: http://www.kew.org/ucm/ groups/public/documents/document/ppcont_013778.pdf .

Şefik Y. 1964. Studies on the cone and seed of Pinus brutia Ten. İ.Ü. Orman Fakültesi Dergisi Seri A XIV(2): 35-70 (In Turkish, with English summary).
Şefik Y. 1965. Studies on the cone and seed of Pinus brutia Ten. Orman Genel Müdürlüğü Yayını, No. 420/41. İstanbul, Turkey. 94 p. (In Turkish, with English summary).

Skordilis A, CA Thanos. 1995. Seed stratification and germination strategy in the Mediterranean pines Pinus brutia and $P$. halepensis. Seed Science and Research 5: 151-160.

Soriano D, A Orozco-Segovia, J Márquez-Guzmán, K Kitajima A., Gamboa-de Buen, P Huante. 2011. Seed reserve composition in 19 tree species of a tropical deciduous forest in Mexico and its relationship to seed germination and seedling growth. Annals of Botany 107: 939-951.

Thanos CA, PW Rundel. 1995. Fire-followers in chaparral: nitrogenous compounds trigger seed germination. Journal of Ecology 83: 207-216.

Thanos CA. 2000. Ecophysiology of seed germination in Pinus halepensis and Pinus brutia. In Ne'eman G, L Trabaud eds. Ecology, Biogeography and Management of Pinus halepensis and P. brutia Forest Ecosystems in the Mediterranean Basin. Leiden, Holland. Backhuys Publisher. p. 37-50.

Toorop PE, CR Campos, GS Begg, B Locardi, GR Squire, PPM Iannetta. 2012. Co-adaptation of seed dormancy and flowering time in the arable weed Capsella bursa-pastoris (shepherd's purse). Annals of Botany 109: 481-489.

Wardlaw I. 1990. Tansley Review No 27. The control of carbon partitioning in plants. New Phytologist 116: 341-381.

Way DA, SL LaDeau, HR McCarthy, JS Clark, R Oren, AC Finzi, RB Jackson. 2010. Greater seed production in elevated $\mathrm{CO}_{2}$ is not accompanied by reduced seed quality in Pinus taeda L. Global Change Biology 16: 1046-1056. 
